\title{
Correction: National multicentre audit of pregnancy status in general surgery admissions in Scotland
}

Wilson MSJ, Powell-Bowns M, Robertson AG on behalf of the Scottish Surgical Research Group, et al. National multicentre audit of pregnancy status in general surgery admissions in Scotland. Postgraduate Medical Journal 2017;93:480-83.

The following author should be listed as a Collaborator: Ajogwu Ugwu.

(c) Article author(s) (or their employer(s) unless otherwise stated in the text of the article) 2018. All rights reserved. No commercial use is permitted unless otherwise expressly granted.

Postgrad Med J 2018;94:60. doi:10.1136/postgradmedj-2016-134390corr1 